\title{
Time-famine, resource obsession and the good life in a pandemic
}

\section{Andrew Root}

Andrew Root is Carries Olson Baalson Professor of Youth and Family Ministry at Luther Seminary in Saint Paul, Minnesota.

On February $18^{\text {th }}$ my twelve-year-old daughter broke down. She was sick of school. 'Why can't it always be the weekend?' she pouted. On March $18^{\text {th }}$ she sobbed uncontrollably, 'All I want to do is go to school!' Like many middle-class families we had big - or at least busy - plans for 2020 . It turned out instead that we stood by and watched those plans each be cancelled and disappear into the ether dust of Google calendar deletes.

While Covid-19 has taken many lives, and many things, maybe the most direct experience for many families and young people has been the loss of their plans. It's painful to see all the graduations, test prep, sports tournaments, theatre performances, service-learning trips, and more be cancelled or given over to weak online imitations. At one level Covid-19 has forced overly busy families to slow down - which isn't all bad. But the speed of our lives wasn't accidental. Middle-class people and their children across the West had full schedules and late nights because busyness was connected (implicitly or explicitly) to a sense of the good life. Covid-19 can be a reprieve from the exhausting pace. But for this reprieve to be beneficial, we need to face the questions of what makes life good in the first place. Practical theology, at its disciplinary core, reflects on action. The philosophical school which revolves around Charles Taylor's thought has argued that human action cannot be understood unless we see it as connected to embodied imaginations of what is good, of what it means to be living a good life. This paper, then, will explore just this. Drawing particularly on the social theory of one of Taylor's collaborators, German thinker Hartmut Rosa, it will explore how Covid19 relates to time, which in turn thrusts many of us into a crisis of the good 
Time-famine, resource obsession and the good life in a pandemic

life. From this exploration the paper will offer some open and preliminary thoughts about local congregations, exploring what impact this crisis of time and the good life has on the congregation.

\section{Welcome to time-famine}

Hartmut Rosa explains an odd conundrum: the more innovation that is birthed through technology, and the more our social norms shift toward our free identities, the more we find ourselves with not a surplus but a deficit of time. Technology and the freedom to innovate our identity as we wish should give us not less but more time. But it never works this way.

Rosa shows that the more we become fertile in technological gadgets and identity options, the more we find ourselves in a time drought, or what he calls a 'time-famine'. 'In modernity, [people] increasingly feel that they are running out of time, that they are short on time. ${ }^{1}$ Rosa believes no one escapes deprivation. ${ }^{2}$ When modernity is about acceleration, all of us find ourselves in a time-famine. Yet, this time-famine takes unique shape across class distinctions. Rosa sees three layers of this time-famine. The top layers are elites and even the middle class who have 'completely internalized this logic of speeding up. So: saving time is saving money. It is the logic of competition, in particular, that they have internalized, and competition is always related to temporality: "time is scarce, don't waste it." 3 In our contemporary moment, particularly in the US, such people ironically feel less of a rush to get back to work. They control their own time, so they can choose - as a moral choice - to stay home and wonder why others wouldn't.

But those outside this top level feel differently. For them, time is imposed on them. These are folks who often live in the time crunch of the service industry and are the first to feel losses in a neoliberal economy. Some of them live paycheck to paycheck, needing time to pay the rent. Rosa says, 'The people working [these kinds of jobs] are always short on time but usually it is someone else - the boss or the clock - who creates the pressure, and it is not so much coming from the inside. ${ }^{4}$ They feel a time-famine that's imposed on them not by internal but external pressure. In the pandemic some of these people don't have the time to not work they need to stock grocery shelves. And others feel, maybe not the pressure of the boss (having been laid off), but pressure from the coming rent payments. 
Time-famine, resource obsession and the good life in a pandemic

Those in the final layer Rosa calls the 'forcefully excluded' or 'forcefully decelerated'. ${ }^{5}$ These are people who are chronically unemployed, often on disability. Some are homeless. Rosa explains, 'forceful or enforced deceleration is a kind of devaluation of the time you have'. ${ }^{6}$ You're in a time-famine not because you feel an internal drive to speed up, or you have a boss that demands it, but because culturally your time has no value.

This expansive and multidimensional time-famine leads everyone into resource obsession. It only makes sense: scarcity has a way of making everything into a resource. Because we all feel in one way or another starved for time, we desire to accrue the resource of time. Resources become valuable because they can be used to meet future contingencies. A resource by definition is a "source or supply from which a benefit is produced and that has some utility. Resources can broadly be classified upon their availability'. ${ }^{7}$ Benefit and availability make resources valuable.

Resources are always about time. They're held onto tightly or sought vigorously because we all feel ourselves in some kind of time-famine. Harvested resources are a way of dealing with the contingencies of the future - like a global pandemic (which explain what happened to all the toilet paper).

We're led to believe that the only way to overcome the time-famine is to win more resources. As we'll see, this approach only obscures our sense of the good life. And turns into an obsession with resources, which impacts the self-understanding of congregations.

\section{Resource obsession and the good life}

The Western time-famine is the result of two felt forces: (1) the overall acceleration of the modern project, and (2) the compression of the present brought on by this acceleration. Inside this compressed present, we can barely find the time to live in the present at all. Our minds are rarely where our bodies are. This is the imposed disease of the Western time-famine. Our bodies may be in the present, but our minds and our imaginations have already left the present, jumping into the future.

This has the effect for most people of making the present too short to allow for any answer on what makes for the good life. The good life cannot be lived out in the present, because our attention to the good is not in the present. Instead, we have sped into the future, riding on the well-worn road 
of the new. How could the good have anything to say about my present? The present is too short, decaying too rapidly to allow for it to hold our imagined or material constitutions of the good life.

Moving so quickly, we keep our imaginations always on a future we can create. We focus on what will be. Yes, people are still seeking the good life. But we are often unable to find the good life in this radically compressed present. With little connection to the present, the good life is without content. Few people can say with any precision what a good life actually is in late modernity. Somehow, this inability to express the good life in the present becomes a good itself, because it allows each individual the freedom to find his or her own future sense of the good. It provides space for you to find some future good through the project of your self. The good, still important in a time-famine, is projected entirely onto the screen of the future. And because it is, the good is without content - not bound in practices, traditions, or communities. It's open, which is both exciting and disorienting. It becomes particularly disorienting when the future comes to an abrupt end. When a pandemic comes and all the activities that we rushed into, to harvest resources for some future good, are over. And when we can get back to full schedules and a sense of speeding toward a good life is unknown. We are given only the present ... but late-modern people have very little sense of the good life in present, in the now.

\section{Dreaming of the future}

Without content to the good life, the best way to prepare for a good life that is always before you is to harvest enough resources to achieve whatever future sense of the good life you want. You can't know or even live the good life now, but you can harvest resources that will make the future good. Having these resources, you can feel good about your present. You can even compare yourself to others by counting resources. Your future is brighter! That makes you feel good now, but its goodness is completely contingent on the resources you possess for some future undefined good life. What this shows is that you don't really feel good about the life you're living now; you feel good about the resources you have that give you the reach and scope to live some future good life. You have the resources for a future good life but never the content of the good life itself. You have no real practices, traditions, or communities that 
mould your sense of the good life in the present. But you do have resources to possess some undefined future good life in some undefined future.

When the good life is cast against the future (not the present), it becomes more individualized and it also wears the marks of a dream. The shape of the good life for the future is the ability to live your dream. Parents at that top layer of the time-famine judge their own goodness as a parent by their ability to give their child resources so that the child can ... we're not sure, but we are sure that resources will give them every chance of living whatever dream their individual self discovers for itself.

Rosa says it this way:

Modern society might not have an answer to what the good life is or what it consists in, but it has a very clear-cut answer to what the preconditions for living a [future coming] good life are, and what to do to meet them: Secure the resources you might need for living your dream (whatever that might be)! has become the overruling rational imperative of modernity. ${ }^{8}$

We become resource-obsessed because the shape of our good life is projected into the future, bound in the dream state. When the good life is for the future, the present is for harvesting as many resources as you can, so that you can live your personal dream in each ever-coming future. We can start to spot why cancelled sports seasons and test prep and so much more can become an existential crisis for young people and their parents.

A more direct concrete example may help. In March 2019 the FBI uncovered a massive college admissions scandal in the US. Elite parents bribed, lied and cheated the system to get their children into elite colleges. Most of us wondered why. These young people didn't need a university degree from Yale to get a good job. And they didn't need a good job to live a life of privilege. If university is for making your financial future brighter, they not only didn't need to go to USC, but didn't really need to go to university at all.

But this misses how the good life is completely projected onto the future, making resources essential for meeting whatever dream you might have in any of the coming lifetimes you might live. The point of getting their children into Yale or USC wasn't to give them a chance to make more money but to give them another important (status) resource they could use to live out whatever dream they might want in the future. Their goal wasn't 
Time-famine, resource obsession and the good life in a pandemic

to give their children the content of a good life. As good late-modern parents, their goal was to give their children the resources they would need to live whatever good life they could individually dream of. Rosa adds insight to this mentality: 'No matter what the future might bring, it will help if you have money, rights, friends, health, knowledge. ${ }^{9}$ In light of these parents, we could add to Rosa's list a university degree from an elite school.

Though these parents had every financial advantage, they felt stuck in an absolute time-famine. They didn't have time to raise their kid's SAT scores or time for their children to be on the crew team. Without time, the most efficient, fast way to be a good parent and give their children the resources they would need to live their dream of a good life was to game the system.

In the end, getting into Yale wasn't for the money; it was for the resource. Rosa says it powerfully:

The ethical imperative that guides modern subjects is not a particular or substantive definition of the good life, but the aspiration to acquire the resources necessary or helpful for leading one. In a way, we moderns resemble a painter who is forever concerned about improving his materials - the colours and brushes, the air condition and lighting, the canvas and easel etc. - but never really starts to paint. ${ }^{10}$

\section{When the dream becomes a nightmare}

With this sense of the good projected onto the screen of the future, taking the shape of a dream, how do you ever arrive at it? When are the resources ever mobilized for living in the present? When do we stop seeking to accrue resources and live? Late-modern life always has a deep pinch of discontent. But you can medicate the discontent, numbing yourself to the pinch by staying with the dream, by never really living in the present. Just keep adding to what you want in the future.

All this means that the resources you have are never enough! The only response to this realization is to speed up to get more resources, projecting your sense of the good further and further into the future, shoring up risk and planning for contingencies. Of course, a pandemic is hard to anticipate - but nevertheless many parents feel guilty that somehow they couldn't 
protect their children from the losses it brought. The pandemic reveals a truth hard for late modern people to face - that that we are finite creatures, and even with storehouses full of resources we cannot live beyond ALL risk to our dreams. Nevertheless, this mentality of a future good life won through accrued resources means enough is never enough because the good that would satisfy is always out beyond you in the unattained future.

This never-ending projection into the future, to secure the dream, induces us further into a time-famine (it's a vicious circle). We are like farmers who have overharvested the land. Instead of letting it rest and living in the present, we work harder to use infertile soil to produce the resources we believe we need for some coming future. Most late-modern people choose the time-famine of the always-future good over the thin emptiness of the present. Until a pandemic forces you into the present, spending all day looking at the market to make sure not too many resources and future dreams have disappeared. The vicious trick of late modernity is to invite us to live in a compressed present where we are free to chase our dreams but never really possess them. Novelist David Foster Wallace, maybe more than anyone else, saw this tragic conundrum back in the 1990s. He saw that you could never actually inhabit the good life you seek, because in the end it has no substance in the present.

Like Wallace, some discover the tragic truth that they've actually achieved the core material marks of the good life they've dreamt of (a bestseller, awards, prestige, global fame). Yet, their dream feels empty, nothing like the dream promised, nothing like the dream-state itself. The good of the present is no match for the good of the dream-state of the future. Having your dream feels deeply disappointing because the sensation of a future newness can never bear the heavy actuality of the present. The flatness of this dream happens because, in the modern age, the present is made dry and arid in order to allow the future and newness itself to become the higher good. Now that you have your dream in the present, it's no longer new, and therefore it's degraded. The present is always desolate because it is absent of the good life itself. The good is always in some future we need to speed ourselves into. The time-famine, then, isn't just due to simply not having enough time. Worse, it makes the present both short and barren.

The tragic story of Wallace is that, feeling this acutely, he ends his life. Wallace's story is hard to accept for late-modern people. Here was a talented young man who was living his dream. And yet he decided to end 
his life, even with his possession of stockpiled resources. Like looking at the sun, it will burn our retinas if we gaze too intently at Wallace's story. Staring too long at his life story reveals that the future and its dreams never deliver the good we long for. The future dream-state can never really be a place where we can rest and live inside. Wallace tragically reveals that it's best to never arrive at your dream. It's better to just keep moving the goalposts, editing your dream to keep it always in the future. It's better to continue to chase more resources than to risk the present delivering a malaise of meaninglessness.

This is a legitimate strategy, until moving the goalposts and chasing resources for the future dream leaves you deeply fatigued. Too tired to keep reaching for the dream, you might start to despise the dream, hating it for leaving you depleted, depressed, and burned out. Your depression is heavy because you tacitly come to sense that not only is the present arid and meaningless, but even the future has turned on you. The dream is running away from you too fast for you to ever have the time to possess enough resources to receive the reward of its good. It is a deeply fatiguing thought to race and race, surviving the time-famine to get to your dream, only to realize it has gotten you nowhere. With the dream in your possession, its beauty fades because its beauty was bound in the future. It becomes a shock to realize that living in the time-famine of chasing resources for your dream is much better (though more fatiguing) than the meaninglessness of possessing your dream in the present.

This sense of a time-famine and the good life also makes its way into our perceptions of our congregations. Pastors and denominational officials often take it in. They come to believe that the only way into the good (into being a good congregation) is to somehow harvest more resources. Only the congregation that is seeking future resources will survive (the congregation with more members, more programmes, more relevance). But how can you do this if you don't have the time? And how could a little church for instance, ever be a resource for people chasing their future good? The church once (in our history) helped people live the good life in the present. Now the good life is lived in the future, not the present. Thus, people want resources from the congregation. They want help coping with their own time-famines, they want assets for their children, and they want tips for obtaining their dream. Enter megachurches and gigachurches like Rick Warren's Saddleback and Joel Osteen's Lakewood, and the thousands of less famous examples. People living in this short present 
Time-famine, resource obsession and the good life in a pandemic

ultimately want help coping with their fatigue, so they can go faster and get more resources for their dream.

A little church had great importance when the good life was lived out in the present where practice, tradition, and community were important. When we were not in a time-famine, a little church had potency. Yet inside the time-famine, when the good life is a dream for the future and the now is about harvesting resources, a little congregation is rendered completely impotent. And a pastor's imagination of her vocation - her own practical ecclesiology - is captured by the sense that she needs to innovate more resources or her congregation will perish (hence, in the US the most common word that denominational officials, seminary presidents and church consultants use is innovation, believing innovation will save dying churches, not recognizing how such a logic rests on a problematic sense of the good life and concession to late-modernity).

\section{The Triple-A}

Of course, most people don't take the tragic step that David Foster Wallace did (though the spiking opioid crisis and young adult depression may point to some of the same phenomenon). Most of us have found a way to live in this arid and short present. You find meaning by seeking the resources for your dream, whatever that might be. Always seeking these resources also means that, even in the midst of a time-famine, you can take on a style or disposition that gives you a sense of living a good life. It remains contentless (or allows you to infuse it with your own individual sense of what's good for you), but it nevertheless is a way of living 'well' while you harvest resources and chase your dream. You can do this by taking on what Rosa calls a 'Triple-A' approach to the good life. He explains, 'the modern way of acting and being-in-the world is geared toward making more and more of its qualities and quantities available, accessible and attainable. ${ }^{11}$ The person (or institution) who is able to 'thrive' in the short present, while always being free to chase a future dream, seeks availability, accessibility, and attainability. (The 'best' congregations are those that provide the most availability, accessibility, and attainability.)

To make this more concrete, let's return to the college-admissions scandal. Why break the law to get your kid admitted to Yale or USC? For those from elite families, the degree likely won't affect the child's earning potential. As a matter of fact, it might risk that earning potential. Suppose 
the child reads Wittgenstein in a first-year philosophy class and decides to be a philosophy major. Or worse, decides to pursue a $\mathrm{PhD}$ in philosophy and become an academic. This will have negative financial impact. But even this rare possibility is worth the cheating and illegal activity, because in the end what matters is not the degree at all. The child doesn't need the degree to increase earning potential. Going to an elite university matters to these families not for the degree but for the availability, accessibility, and attainability it offers. Getting into a top school like Yale gives you availability to important people, accessibility to exclusive institutional status, and an overall attainability of whatever dream you wish.

These elite parents lie and cheat to get the Triple-A. Universities can charge $\$ 50,000$ a year because, as we all know, they don't offer strictly teaching and learning. Few of us would pay that sticker price for just teaching and learning (which is a shame but a reality). People are paying that huge amount of money for availability, accessibility, and attainability. We might complain and even go into debt, but we are all willing to spend this huge amount of resources in exchange for these other resources of availability, accessibility, and attainability.

For people living in the first layer of Rosa's time-famine - those of us who feel the internal deficit of time - it's not an option for our children NOT to go to university. Yet, we don't fear that they'll never read Plato or Dickens, study biology, or understand economics. What frightens us is that they'll have a future deficit of availability, accessibility, and attainability. Without these resources, we assume, they'll never be able to live their dream, never find their way into some future good life (and therefore die of unhappiness).

We ask our children and ourselves to rush, to accelerate the pace of our lives to do more in less time, so that we can achieve the resources that will give us availability, accessibility, and attainability. When it comes to teaching and learning, a humble school like Minnesota State may be just as good as USC or Oxbridge. But Minnesota State is nowhere close when it comes to producing availability, accessibility, and attainability. Matriculating at one of these elite schools gives you a sense that the future promises a good life.

Acceptance to your dream college is the perfect late-modern dream. It allows for a sense of accomplishment - you're in the school you always dreamed of - but obtaining this dream is only about other future dreams. The cultural currency of university gives you the Triple-A for another 
Time-famine, resource obsession and the good life in a pandemic

dream in the future. University is a must because whatever dream you're chasing, you'll always need availability, accessibility, and attainability. This is what unconsciously goes through our heads as we write each monthly student loan check.

\section{The style and scope of the Triple-A}

We need to explore a little deeper. The Triple-A is important because, by delivering direct resources, it offers a style or way of being in relation to the world. This style allows the flat, meaningless, and even good-lifevapid present to be nevertheless inhabitable. You inhabit this short present by keeping your eyes on the goods of your future dream, while seeking availability, accessibility, and attainability in the present. And you should choose to affiliate with friends and institutions that also have availability, accessibility, and attainability. They will give you more of these three resources, which further sets you up to attain your dream.

Ultimately, the Triple-A produces scope. In a short present, where the good is always in the future, having scope is a way to nevertheless relate to the world in the present. To have scope is to have room to act, an ability to cover a large range. The good life might still be out in the future - you might still be chasing your dream and not accomplishing much of it - but if you have scope, you can have esteem. You show that you're relating to the world in a manner that promises you all the future resources to get your dream.

Rich kids need to go to Yale and USC not so they can be learned or intellectually formed but so they can have the style of scope. Scope means you can go to a dinner party and have someone whisper, There's Madeleine. She's so interesting! She started her own charity after visiting Mozambique. In ninth grade she launched a nail polish business. She has three hundred thousand Instagram followers, AND she went to Yale. That's scope!

It's characters with this kind of scope that make Wes Anderson's films so interesting. The children in Rushmore and The Royal Tenenbaums have a humorous amount of scope. Their parents see it as a style necessary for a future good life. Of course, in most of Anderson's films, these children, moulded for scope and with a bright future always before them, get stuck. Having little else than scope, they're tortured by an absence of any real connection to a tangible good life. 
Anderson's characters, or Madeleine in the example above, sense that the good is completely a projection into the future. But Madeleine relates to the world in the present through scope. And scope, to make this circular, reveals that she's the kind of talented person who can relate to the world in such a way that she can innovate, maximize, and accrue resources. Her future is bright. Her dreams will come true! (This never happens in Anderson's films.) She might not have her dreams now, but she has scope (men and women want to be with her and women want to be her), which is as good as a down payment.

\section{Misguided scope}

Scope isn't bad in itself. Because it's a way of relating to the world, it reveals something fundamental about us. We hope for some kind of scope. But in late modernity, inside a time-famine, we can only imagine the good on some future plane. This makes it difficult to find a speaking, living, breathing world in the present - and difficult for people in our congregations to have the eyes to see a living God moving in their lives, speaking life to their many experiences of death and loss in the now.

Our desire for scope shows our longing to encounter something transcendent. Yet Rosa contends that, unfortunately, we allow scope to be flattened into style. As style, scope has no referent or aim beyond itself. Scope becomes self-referential, as Wes Anderson's characters show, spinning deeper into self-actualizing projects, which enclose the actor deeper within the aridness of the hollowness of the present. Rosa says it this way: "Alas [...] instead of arriving [at scope], we end up turning the business of increasing our scope and horizon of the available, attainable and accessible, and collecting resources into an end in itself, into an endless, escalatory cycle which permanently erodes its own basis and thus leads nowhere.' 12

And this takes us back to our present crisis. Covid-19 produces many burdens but maybe an acute one is the burden of the present. People are forced to be in the present with little sense of when they can get back to procuring the resources needed for their dreams. This opens up all sorts of questions about ministry and theology in this moment. Most particularly, it asks, How can we find ways to reflect directly with people on what a good life is (particularly through the vision of a God who is crucified and resurrected)? And it asks, What practices are needed, and what shape of 
Time-famine, resource obsession and the good life in a pandemic

congregational life is necessary, to help people live in the present and seek for a God in the heaviness of our now?

\section{Notes}

1 Rosa, Alienation and Acceleration: Towards a Critical Theory of LateModern Temporality (Malmö, Sweden: NSU Press, 2014), 20.

2 Rosa discusses the time-famine further in Social Acceleration: A New Theory of Modernity (New York: Columbia University Press, 2015), 309-10.

3 Rosa, "Beyond the Echo Chamber", in Thijs Lijster, Future of the New: Artistic Innovation in Times of Social Acceleration (Amsterdam: Valiz, 2018), 27.

4 Ibid., $27 \mathrm{f}$.

5 Rosa discusses this further in "De-Synchronization, Dynamic Stabilization, Dispositional Squeeze: The Problem of Temporal Mismatch", in The Sociology of Speed: Digital, Organizational, and Social Temporalities, ed. Judy Wajcman and Nigel Dodd (Oxford: Oxford University Press, 2017), 25-41.

6 Rosa, "Beyond the Echo Chamber", 28.

7 "Resource", Wikipedia, accessed January 19, 2020, https://en.wikipedia.org/wiki/Resource.

8 Rosa, "Two Versions of the Good Life and Two Forms of Fear: Dynamic Stabilization and the Resonance Conception of the Good Life", paper presented at the Yale Center for Faith and Culture conference on Joy, Security, and Fear, New Haven, Conn., November 8-9, 2017, 7 (emphasis original). See also Rosa, "Available, Accessible, Attainable: The Mindset of Growth and the Resonance Conception of the Good Life", in The Good Life Beyond Growth: New Perspectives, ed. Hartmut Rosa and Christoph Henning (London: Routledge, 2019), 41.

9 Rosa, "Two Versions of the Good Life", 7 (emphasis added).

10 Ibid. This is why Rosa thinks that acceleration is able to so deeply nestle into our lives. It actually becomes a strategy of dealing with - or better - avoiding death. See Rosa, Alienation and Acceleration, 30-35, for a longer conversation on this point. 
Time-famine, resource obsession and the good life in a pandemic

11 Rosa, "Available, Accessible, Attainable", 42 (emphasis added).

12 Ibid., 45.

This paper is adapted from chapter 12 of The Congregation in the Secular Age: Keeping Sacred Time Against the Speed of Modern Life by Andrew Root (C) 2021 Baker Academic, a division of Baker Publishing Group http://bakerpublishinggroup.com/ and is used by kind permission of the publisher. 